\title{
OPEN Modeling and optimization of radish root extract drying as peroxidase source using spouted bed dryer
}

\author{
Shahrbanoo Hamedi ${ }^{1}$, M. Mehdi Afsahi ${ }^{1 \bowtie}$, Ali Riahi-Madvar ${ }^{2 \varpi}$ \& Ali Mohebbi $^{1}$
}

The main advantages of the dried enzymes are the lower cost of storage and longer time of preservation for industrial applications. In this study, the spouted bed dryer was utilized for drying the garden radish (Raphanus sativus $\mathrm{L}$.) root extract as a cost-effective source of the peroxidase enzyme. The response surface methodology (RSM) was used to evaluate the individual and interactive effects of main parameters (the inlet air temperature $(T)$ and the ratio of air flow rate to the minimum spouting air flow rate (Q)) on the residual enzyme activity (REA). The maximum REA of $38.7 \%$ was obtained at $\mathrm{T}=50^{\circ} \mathrm{C}$ and $\mathrm{Q}=1.4$. To investigate the drying effect on the catalytic activity, the optimum reaction conditions ( $\mathrm{pH}$ and temperature), as well as kinetic parameters, were investigated for the fresh and dried enzyme extracts (FEE and DEE). The obtained results showed that the optimum $\mathrm{pH}$ of DEE was decreased by $12.3 \%$ compared to FEE, while the optimum temperature of DEE compared to FEE increased by a factor of $85.7 \%$. Moreover, kinetic parameters, thermal-stability, and shelf life of the enzyme were considerably improved after drying by the spouted bed. Overall, the results confirmed that a spouted bed reactor can be used as a promising method for drying heat-sensitive materials such as peroxidase enzyme.

Enzymes are protein catalysts extensively used in various industries. However, their sensitivity to heat, especially in the form of liquid, is a major application problem ${ }^{1}$. In this regard, various methods including the use of osmolytes $^{2}$, mutagenesis ${ }^{3}$, immobilization ${ }^{4-7}$, and drying ${ }^{8}$ have been developed to increase the thermal as well as the storage stability of the enzymes. One of the impressive and applicable methods for improving enzyme stability is enzyme drying. This technique significantly reduces the initial solution weight as well as packaging and transportation costs? .

One of the oxidoreductase heat-sensitive enzymes is peroxidase that catalyzes a wide variety of reactions in the presence of peroxides. According to the literature, peroxidase has various applications in industries, such as the removal of the phenolic pollution from the wastewaters, decolorization of the synthetic paints, bio pulping and biobleaching, analysis and diagnostic kits, design and construction of biosensors, and synthesis of aromatic amines, phenolic compounds and polymers ${ }^{10}$. Peroxidase can be extracted from plants and animals or produced by microorganisms in a fermenter ${ }^{10,11}$. The enzyme extraction from the plant sources has considerable advantages including low production cost and renewability ${ }^{12}$. Peroxidase has been extracted from plants such as Brassica rapa, Lycopersicon esculentum, Raphanus sativus L., and Brassica oleracea ${ }^{13-16}$

Few papers have been published about enzyme drying by spouted bed ${ }^{17}$. Many studies have been published on spouted bed drying in other fields of studies such as food industries and pharmaceticals ${ }^{18,19}$.

According to relevant literature reviews, several methods have been applied for the preparation of enzyme powder, including freeze drying ${ }^{20}$, spray drying ${ }^{21-23}$, and spouted bed drying ${ }^{17}$. Spray drying of alpha-amylase ${ }^{20}$, protease $^{22}$, lipase $\mathrm{e}^{24}$, freeze-drying of alpha-amylase ${ }^{20}$ and spouted bed of lipase ${ }^{17}$ are examples of enzyme drying. Among the mentioned dryers, the spouted bed can be used as an effective drying equipment, due to its advantages such as low $\cos ^{25}$, ability to work at low temperature, and high volumetric evaporation rates under identical thermal conditions ${ }^{26}$.

In this study, Peroxidase was extracted from garden radish (Raphanus sativus L.) as a low-cost source ${ }^{27}$ and a full factorial experimental design was employed to evaluate the influence of input operating variables (inlet

${ }^{1}$ Department of Chemical Engineering, Shahid Bahonar University of Kerman, Kerman, Iran. ${ }^{2}$ Department of Molecular and Cell Biology, Faculty of Basic Sciences, Kosar University of Bojnord, Bojnord, Iran. ${ }^{\square}$ email: afsahi@uk.ac.ir; riahi.ali@gmail.com 


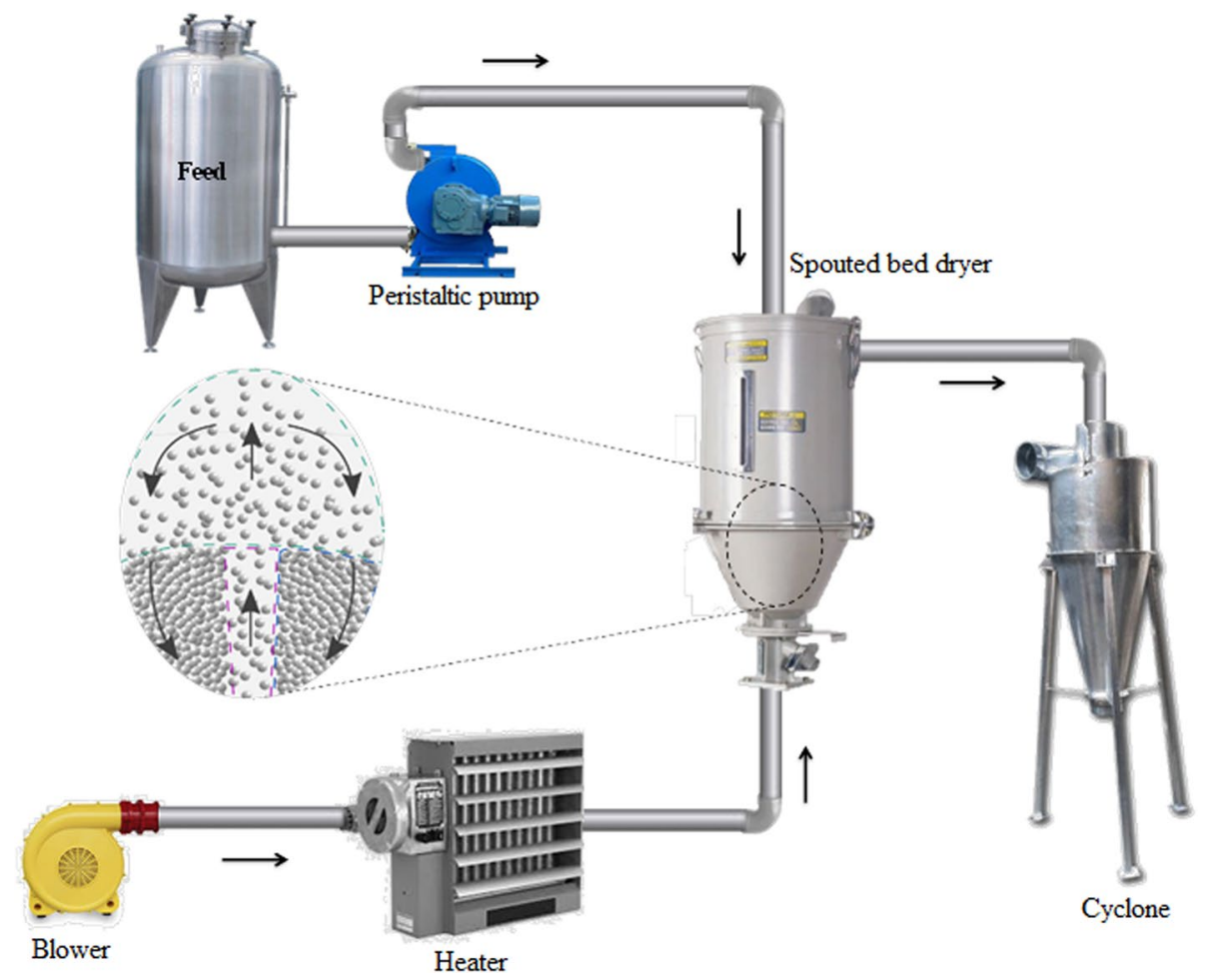

Figure 1. Schematic diagram of the spouted bed dryer.

air temperature and flow rate) on drying by spouted bed. After process optimization, an enzymatic reaction in the presence of the fresh enzyme extract (FEE) and dried enzyme extract (DEE) was carried out to evaluate the enzyme catalytic activity. Kinetic parameters of the enzymatic reaction $\left(V_{\max }\right.$ and $\left.K_{\mathrm{m}}\right)$ were obtained using Michaelis-Menton (M-M) equation. Moreover, the thermal stability and shelf-life of FEE and DEE were determined and compared. To the best of our knowledge, no experimental or modeling study has been investigated on the peroxidase drying by a spouted bed.

\section{Materials and methods}

Materials. The roots of the garden radish were purchased from a local market, Kerman, Iran. Also, hydrogen peroxide $\left(\mathrm{H}_{2} \mathrm{O}_{2}\right), 3,3^{\prime}, 5,5^{\prime}$-tetramethylbenzidine (TMB), dipotassium phosphate $\left(\mathrm{K}_{2} \mathrm{HPO}_{4}\right)$, Monopotassium phosphate $\left(\mathrm{KH}_{2} \mathrm{PO}_{4}\right)$, bovine serum albumin (BSA), and Coomassie Brilliant Blue G-250 (CBBG) were all purchased from Sigma-Aldrich (St. Louis, MO, USA). Double distilled water was used in all experiments.

Enzyme extraction and quantification. The enzyme extract was obtained using the technique defined by Riazi et al. ${ }^{15}$ with a slight modification. The garden radish roots were peeled and the extract was prepared with a juicer. The slurry solution was then filtered, homogenized, and stored in a freezer $\left(-20^{\circ} \mathrm{C}\right)$ until used. The total protein concentration of the extract was estimated according to Bradford's method ${ }^{28}$ using bovine serum albumin (BSA) as standard. All experiments complied with relevant institutional, national, and international guidelines and legislation.

Drying procedure. The drying procedure was performed in a spouted bed consisting of a plexiglass cylindrical column with an inner diameter of $90 \mathrm{~mm}$ and a height of $300 \mathrm{~mm}$ that was connected to the conical base of the dryer (the internal angle of $60^{\circ}$ and the inlet orifice diameter of $15 \mathrm{~mm}$ ). Details of the used spouted bed and experimental procedure can be found in our previous published paper $^{18}$. The main components of the system were a heater with two elements by total power of $8 \mathrm{~kW}$, a blower with a power of $2.2 \mathrm{~kW}$ (GREENCO 2RB, China) which was equipped with a three-phase inverter, a peristaltic pump (WPX-1, Welco Co., Japan), an air flow meter, and a cyclone (Fig. 1). The temperature and humidity of the inlet and outlet air were controlled using the sensors installed at different points. Glass granules (diameter $3 \mathrm{~mm}$, sphericity 1, density $2343.1 \pm 9.8 \mathrm{~kg}$ / $\mathrm{m}^{3}$ ) were considered as the inert materials to be a carrier for the liquid film, a conductive heat transfer medium, and a mechanical cleaner of the bed ${ }^{29}$. When the outlet air temperature showed a constant value by Data Logger (Testo, T4 176), a constant feed flow rate with $1.22 \pm 0.09 \mathrm{ml} / \mathrm{min}$ was dropped on the glass beads $(360 \mathrm{~g})$ using the peristaltic pump. The drying process was performed according to convective and conductive heat transfer in the bed. At the end of each experiment, the produced powder at the bottom of the cyclone was collected to analyze the enzyme activity. After each test, the granules were removed from the bed, washed several times, and dried for further use. 


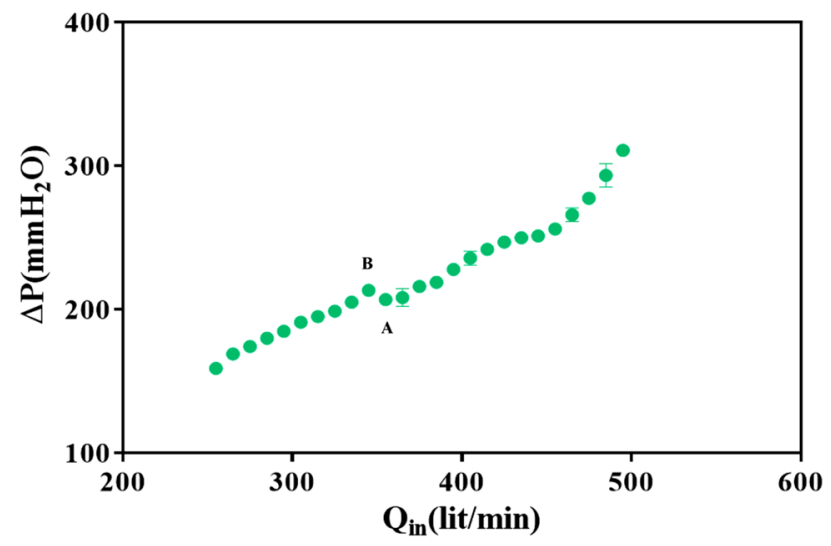

Figure 2. Pressure drop $(\Delta \mathrm{P})$ versus the inlet air flow rate $\left(\mathrm{Q}_{\text {in }}\right)$.

Minimum spouting air flow rate. The minimum air flow rate to spout the inert glass beads $\left(\mathrm{Q}_{\min }\right)$ was determined according to the method developed by Mathur and Epstein ${ }^{30}$ from the curve of the bed pressure drop versus the air flow rate $\left(\mathrm{Q}_{\mathrm{in}}\right)$. It was obtained experimentally by slowly decreasing the air flow rate. Point $\mathrm{A}$ in Fig. 2 represents the minimum spouting condition where the bed remains in the spouted state. A slight reduction of air velocity at this condition causes the spout to collapse and the pressure drop to rise suddenly to point B. The bed pressure drop and air flow rate were measured using a digital differential manometer (Testo 510i) and a rotameter, respectively. Each experiment was repeated three times to provide an acceptable level of reliability.

Residual enzyme activity (REA). Peroxidase activity was determined according to the procedure described by Krainer et al. ${ }^{31}$. The reaction was started by the addition of $1 \mathrm{mM} \mathrm{H}_{2} \mathrm{O}_{2}$ to a solution including $0.6 \mathrm{mM}$ TMB, $50 \mathrm{mM}$ potassium phosphate buffer, and the enzyme extract. The optical density was measured at $653 \mathrm{~nm}$ (extinction coefficient of oxidized TMB was $3.9 \times 104 \mathrm{~mol} / \mathrm{cm}$ ) by a spectrophotometer (Cary 50 , Australia) for $180 \mathrm{~s}$. The specific activity is defined as the ratio of the enzyme activity to the total protein amount ${ }^{32}$. REA was calculated as the ratio of the specific activity of the enzyme powder to the specific activity of the enzyme extract, as shown in Eq. (1) ${ }^{17}$ :

$$
\text { REA }=\frac{\text { Specific activity of the powder enzyme }}{\text { Specific activity of the extract enzyme }} \times 100 \text {. }
$$

Experimental design. To evaluate the effect of drying conditions on the REA, the experimental design was conducted at different inlet air temperatures and flow rates. Minitab 17 software was used to design the experiment and analyze the obtained data. A full factorial design, considering the inlet air temperature at three levels of $50,60,70^{\circ} \mathrm{C}$ and the dimensionless air flow rate at two levels of 1.2 and 1.4 resulted in 18 experiments that were performed with three times replication. To predict REA at different conditions, a first-order polynomial relationship relative to relevant variables has been presented in Eq. (2):

$$
R E A \%=\beta_{0}+\beta_{1} \mathrm{X}_{1}+\beta_{2} \mathrm{X}_{2}+\beta_{12} \mathrm{X}_{1} \mathrm{X}_{2},
$$

where, REA $\%$ is the response of model, $\beta_{0}, \beta_{\mathrm{i}}$, and $\beta_{\mathrm{ij}}$ are the constant, linear, and interaction coefficients of the models, respectively. $\mathrm{X}_{1}$ and $\mathrm{X}_{2}$ are the inlet air temperature and dimensionless air flow rate (the ratio of $\mathrm{Q}_{\text {in }}$ to $\left.\mathrm{Q}_{\min }\right)$, respectively ${ }^{33}$. To achieve the enzyme maximum residual activity, the obtained data were analyzed using RSM. Enzyme powder, obtained under the best drying conditions, was utilized in the subsequent experiments.

The catalytic activity of the enzyme. To evaluate the activity of the dried peroxidase enzyme, the reaction of $0.6 \mathrm{mM}$ TMB with $1 \mathrm{mM}$ hydrogen peroxide in the presence of the DEE and FEE was carried out ${ }^{31}$. The specific activity of the enzyme can be changed by the temperature, $\mathrm{pH}$, and concentration of the substrate. In order to find the optimum value of $\mathrm{pH}$, peroxidase activity was measured at various $\mathrm{pH}$ values from 3 to 10 at ambient temperature. The optimum temperature of the reaction was also determined by the measurement of the FEE and DEE activity during the reaction at different temperature ranges $\left(10-85^{\circ} \mathrm{C}\right)$ under the optimum $\mathrm{pH}^{34}$.

Kinetic parameters of the enzymatic reaction. Under the obtained optimum conditions, the reaction between TMB and hydrogen peroxide was carried out in the presence of the peroxidase and different concentrations of the substrate $(0.06-0.6 \mathrm{mM} \mathrm{TMB})$ and $1 \mathrm{mM} \mathrm{H}_{2} \mathrm{O}_{2}{ }^{34}$. The rate of the reaction at different conditions can be calculated by Michaels-Menten (M-M) equation. By inverting this equation, a linear relationship can be obtained which is called Line weaver-Burke Equation (Eq. (3)). The kinetic parameters of the reaction can be determined from the slope and intercept of this line ${ }^{35}$. 


\begin{tabular}{|c|c|c|c|c|c|}
\hline \multirow[b]{2}{*}{ Run } & \multirow[b]{2}{*}{$\mathrm{T}\left({ }^{\circ} \mathrm{C}\right)$} & \multirow[b]{2}{*}{ Q } & \multicolumn{2}{|c|}{$\begin{array}{l}\text { The residual enzyme } \\
\text { activity (\%) }\end{array}$} & \multirow[b]{2}{*}{ Error (\%) } \\
\hline & & & Experimental & Predicted & \\
\hline 1 & 50 & 1.4 & 42.0 & 39.1 & 7.4 \\
\hline 2 & 60 & 1.4 & 32.9 & 32.0 & 2.8 \\
\hline 3 & 70 & 1.2 & 17.9 & 16.1 & 11.2 \\
\hline 4 & 70 & 1.4 & 27.5 & 25.0 & 10.0 \\
\hline 5 & 60 & 1.4 & 33.5 & 32.0 & 4.7 \\
\hline 6 & 50 & 1.2 & 35.6 & 38.2 & 6.8 \\
\hline 7 & 60 & 1.2 & 30.2 & 27.1 & \begin{tabular}{|l|}
11.4 \\
\end{tabular} \\
\hline 8 & 70 & 1.4 & 23.7 & 25.0 & 5.2 \\
\hline 9 & 60 & 1.2 & 27.3 & 27.1 & 0.7 \\
\hline 10 & 50 & 1.2 & 41.8 & 38.2 & 9.4 \\
\hline 11 & 70 & 1.4 & 22.5 & 25.0 & 10.0 \\
\hline 12 & 70 & 1.2 & 14.8 & 16.1 & 8.1 \\
\hline 13 & 70 & 1.2 & 14.4 & 16.1 & 10.6 \\
\hline 14 & 60 & 1.4 & 33.4 & 32.0 & 4.4 \\
\hline 15 & 50 & 1.2 & 35.6 & 38.2 & 6.8 \\
\hline 16 & 50 & 1.4 & 35.9 & 39.1 & 8.2 \\
\hline 17 & 50 & 1.4 & 35.3 & 39.1 & 9.7 \\
\hline 18 & 60 & 1.2 & 25.9 & 27.1 & 4.4 \\
\hline
\end{tabular}

Table 1. The results of full factorial design relevant to the residual enzyme activity.

$$
\frac{1}{V_{s}}=\frac{1}{V_{\max }}+\frac{K_{m}}{V_{\max } S} .
$$

In this equation, $V_{s}$ is the reaction rate $(\mu \mathrm{M} / \mathrm{min} \mathrm{mg}), V_{\max }$ is the maximum reaction rate $(\mu \mathrm{M} / \mathrm{min} . \mathrm{mg})$, and $K_{\mathrm{m}}$ is the M-M equation constant $(\mathrm{mM})$. The product of the mentioned reaction was a colored compound and the color changed with the reaction progress. Therefore, the intensity of light absorption could be determined at different times by a spectrophotometer. Finally, the concentration of the product $\left(\mathrm{C}_{\mathrm{P}}\right)$ at different times was determined from the Beer-Lambert equation. In the plot of $C_{P}$ versus time, several slopes can be obtained at different initial substrate concentrations. The reaction rate $\left(V_{s}, \mu \mathrm{M} / \mathrm{min} . \mathrm{mg}\right)$ was calculated by dividing the slope of plots by the amount of the protein content.

Peroxidase thermal-stability and self-life during storage. To determine the possible variation in enzyme thermal-stability, the DEE and FEE were incubated for $10 \mathrm{~min}$ at different temperature ranges (25$80^{\circ} \mathrm{C}$ ), and then after 5 min incubation at room temperature, enzyme activity was measured ${ }^{2}$. The shelf-life of $\mathrm{DEE}$ and FEE during storage was followed by the determination of the changes in the enzyme activity during storage at $-4{ }^{\circ} \mathrm{C}$.

\section{Results and discussion}

Minimum spouting air flow rate. According to Fig. 2, the minimum spouting air flow rate was observed to be $355 \mathrm{l} / \mathrm{min}$. The ratio of $\mathrm{Q}_{\mathrm{in}}$ to $\mathrm{Q}_{\min }$ in each experiment is a dimensionless parameter for investigating the effect of drying on the residual activity.

Experimental design. Full factorial experiment design methodology and model consequence for REA. The full factorial design matrix with two independent variables and results obtained from empirical experiments and model prediction are shown in Table 1. Based on the experimental data, the following equation Eq. (4) can be expressed as a model that shows a correlation between the REA and the operating variables:

$$
\mathrm{REA} \%=207.4-3.493 \mathrm{X}_{1}-95.1 \mathrm{X}_{2}+1.992 \mathrm{X}_{1} \mathrm{X}_{2} .
$$

To evaluate the importance and suitability of the obtained model, the analysis of variance (ANOVA) was carried out and the results are shown in Table 2. From the table, it can be concluded that the regression model had a high determination coefficient $\left(\mathrm{R}^{2}=0.95\right)$.

As can be observed, all the terms of the model (the linear and interaction terms) have a p-value less than 0.05 , which means that both terms are significantly effective on REA ${ }^{36,37}$. Moreover, the calculated F-value for the regression model is meaningfully higher than the acquired F-distribution, which demonstrates the predicted strength of the fitted model ${ }^{38}$. According to this result, the appropriateness and credibility of the model are confirmed for the simulation of the REA.

The residual analysis was used to further check the model adequacy. This analysis indicates the difference between the experimental data and the computed data by the model. Figure 3 illustrates the residual plots related 


\begin{tabular}{|l|l|l|l|l|}
\hline Source of variations & DF & Adjusted Mean Square & F-value & p-value \\
\hline Regression model & 3 & 378.726 & 86.79 & 0.000 \\
\hline Linear & 2 & 544.288 & 124.73 & 0.000 \\
\hline $\mathrm{T}$ & 1 & 981.021 & 224.81 & 0.000 \\
\hline $\mathrm{Q}$ & 1 & 107.556 & 24.65 & 0.000 \\
\hline $\mathrm{T}^{*} \mathrm{Q}$ & 1 & 47.601 & 10.91 & 0.005 \\
\hline Error & 14 & 4.364 & - & - \\
\hline Lack-of-Fit & 2 & 1.844 & 0.39 & 0.688 \\
\hline Pure Error & 12 & 4.784 & - & - \\
\hline $\mathrm{R}^{2}=94.90 \%, \mathrm{R}^{2}$ adj $=93.80 \%, \mathrm{R}^{2}$ pred $=90.59 \%$ & & \\
\hline
\end{tabular}

Table 2. Analysis of variance relevant to the residual enzyme activity.

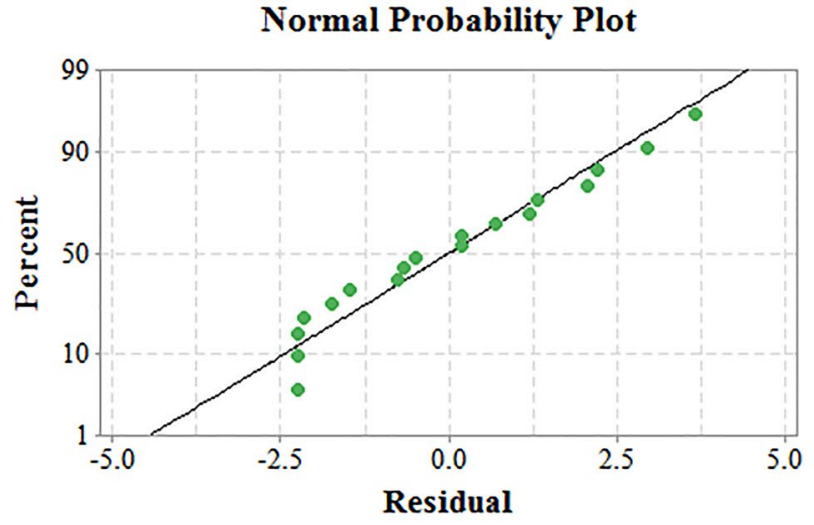

Histogram

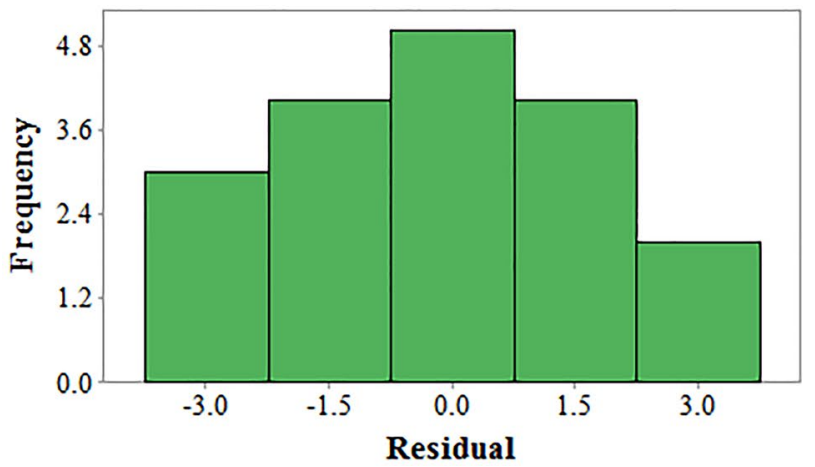

Versus Fits

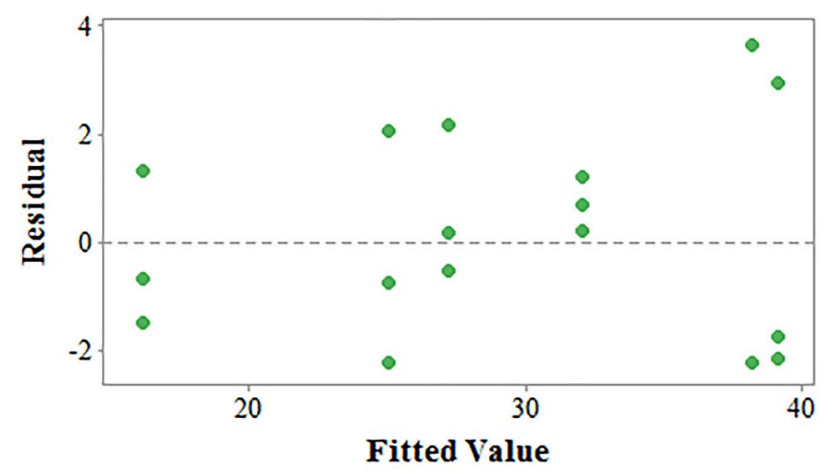

Versus Order

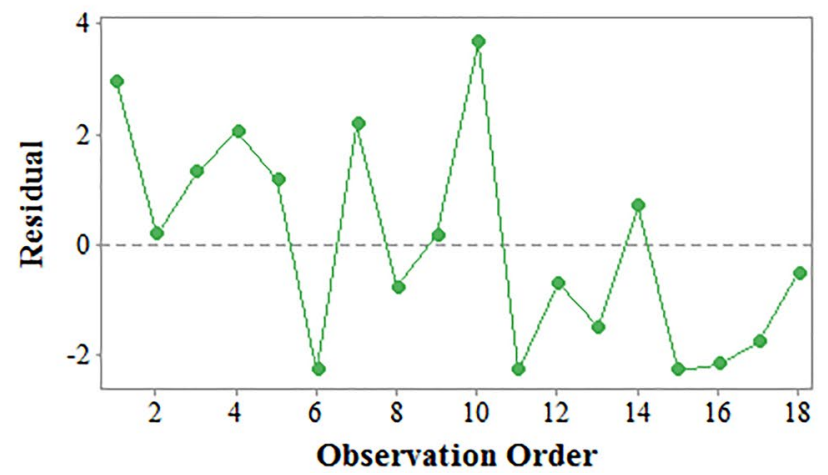

Figure 3. Residual plots for residual peroxidase activity.

\begin{tabular}{|l|l|c|l|}
\hline Terms & Coded coefficient & T-value & p-value \\
\hline$\beta_{0}$ & 29.578 & 60.07 & 0.000 \\
\hline$\beta_{1}$ & -9.042 & -14.99 & 0.000 \\
\hline$\beta_{2}$ & 2.444 & 4.96 & 0.000 \\
\hline$\beta_{1} \times \beta_{2}$ & 1.992 & 3.30 & 0.005 \\
\hline
\end{tabular}

Table 3. Estimated regression coefficients, T- and p-values.

to the residual data which was generated by 18 experimental runs. As can be seen, the tendency in all residual plots follows a normal distribution. Accordingly, it can be stated that the obtained model has good adequacy and satisfactoriness.

Regression analysis of the experimental data including T-values, regression coefficients, and p-values are shown in Table 3. The p-values were used as a tool to evaluate the significance and importance of each coefficient. 


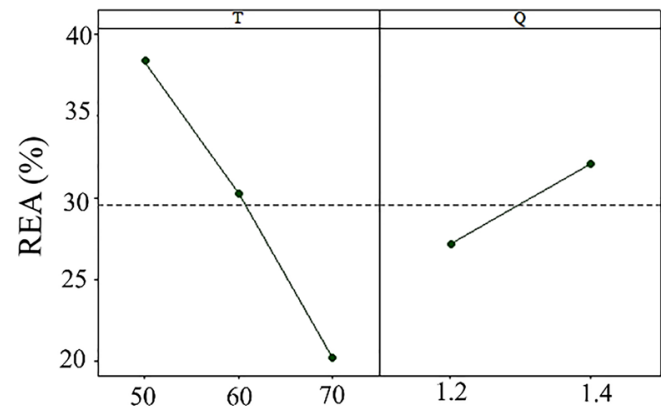

(a)

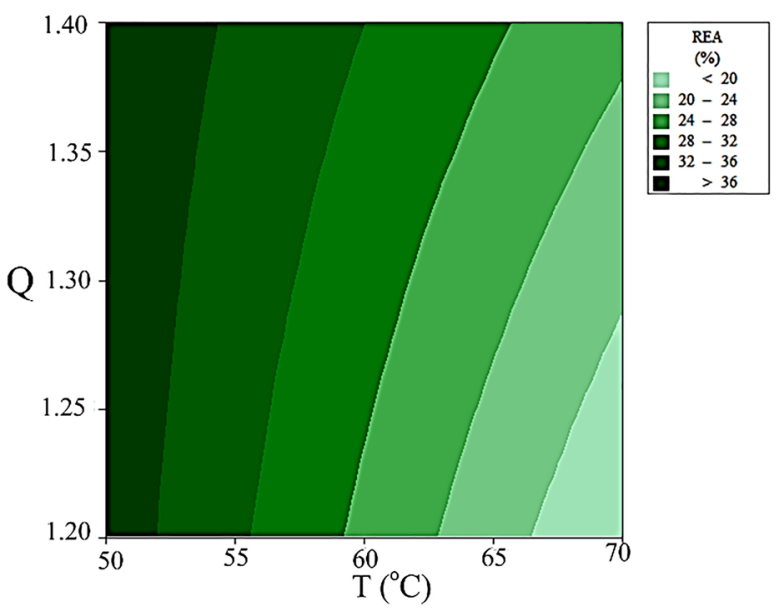

(c)

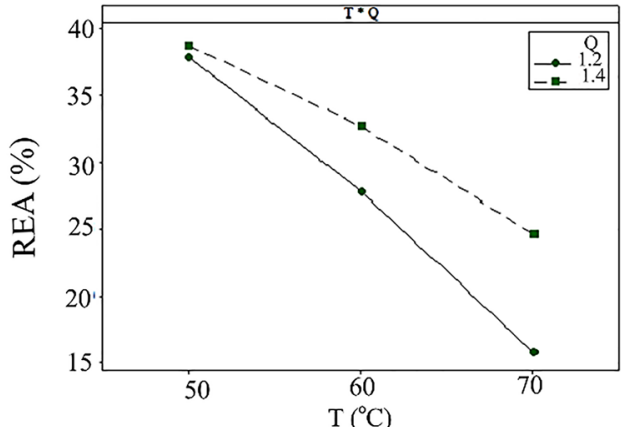

(b)

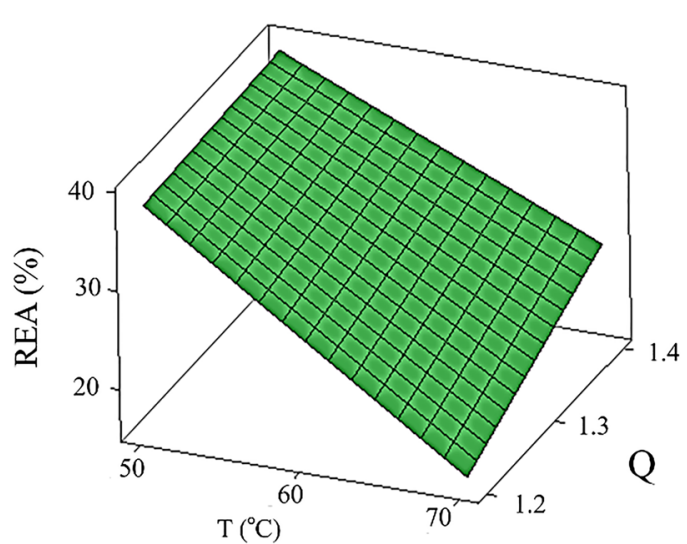

(d)

Figure 4. (a) The effect of the inlet air temperature (T) and the ratio of air flow rate to the minimum spouting air flow rate (Q) on the residual enzyme activity (REA), (b) the interaction effect of T and Q on the REA, (c) the contour and (d) surface plot of the REA (\%).

The higher amount of the T-value and lower amount of the p-value reveal that the corresponding coefficient is more significant and has a greater effect on the response. The results demonstrated that the inlet air temperature $(\mathrm{p}$-value $=0.0)$, flow rate $(\mathrm{p}$-value $=0.0)$, and their interaction $(\mathrm{p}$-value $=0.005)$ were significant parameters in peroxidase drying process. As seen, some of the coefficients are positive and some are negative. The positive or negative coefficients display that these parameters will increase or decrease the response, respectively. Among the discussed parameters, the T had a negative effect on REA while Q had a positive effect.

Effect of the inlet air temperature and flow rate on the REA. The effect of the inlet air temperature and the flow rate on the REA are illustrated in Fig. 4. As it is obvious from Fig. 4a, the flow rate has a positive effect and REA increases with the increment of the flow rate at the constant values of T. Conversely, the inlet air temperature has a negative effect on REA and an increase in the inlet air temperature from 50 to $70{ }^{\circ} \mathrm{C}$ leads to a decrease in the REA. The results in Fig. 4a demonstrate that at higher inlet air temperatures, the positive effect of the inlet air flow rate was more noticeable on REA, compared to lower temperatures. Furthermore, the slope of lines in Fig. $4 \mathrm{~b}$ is different, which indicates the importance of the effect of each factor on the REA.

To further investigate the influence of each factor on REA and to discover the relative optimum range, the contour and surface plots were obtained. Figure $4 \mathrm{c}$,d depict the contour and surface plots as a function of two input operating factors. The darker area in Fig. $4 \mathrm{c}$ indicates the higher amount of REA. Figure $4 \mathrm{~d}$ represents the effect of the temperature and the air flow rate on REA; the maximum of these parameters occurred at $\mathrm{T}=50^{\circ} \mathrm{C}$ and $\mathrm{Q}=1.4$.

According to the obtained results, it was found that by increasing the temperature, the REA decreased, which agrees with earlier research ${ }^{22,23}$. Indeed, increasing the temperature can change the chemical structure of the enzyme and therefore reduce the enzyme activity. On the other hand, at the higher inlet air flow rate, due to the lower residence time of the powder, the enzyme was less affected by the heat and then the amount of the REA increased. Under the best drying conditions $\left(\mathrm{T}=50^{\circ} \mathrm{C}\right.$ and $\left.\mathrm{Q}=1.4\right)$, the REA was obtained to about $38.7 \%$.

Effect of drying on the catalytic activity of the enzyme. The effect of $\mathrm{pH}$ on the enzymatic reaction at $25^{\circ} \mathrm{C}$ has been shown in Fig. 5a. By increasing the $\mathrm{pH}$ value from 3 to about 5.75 for FEE and from 3 to 5 for DEE, the specific activity of the enzyme was enhanced. Further increase in $\mathrm{pH}$ value reduced the residual 

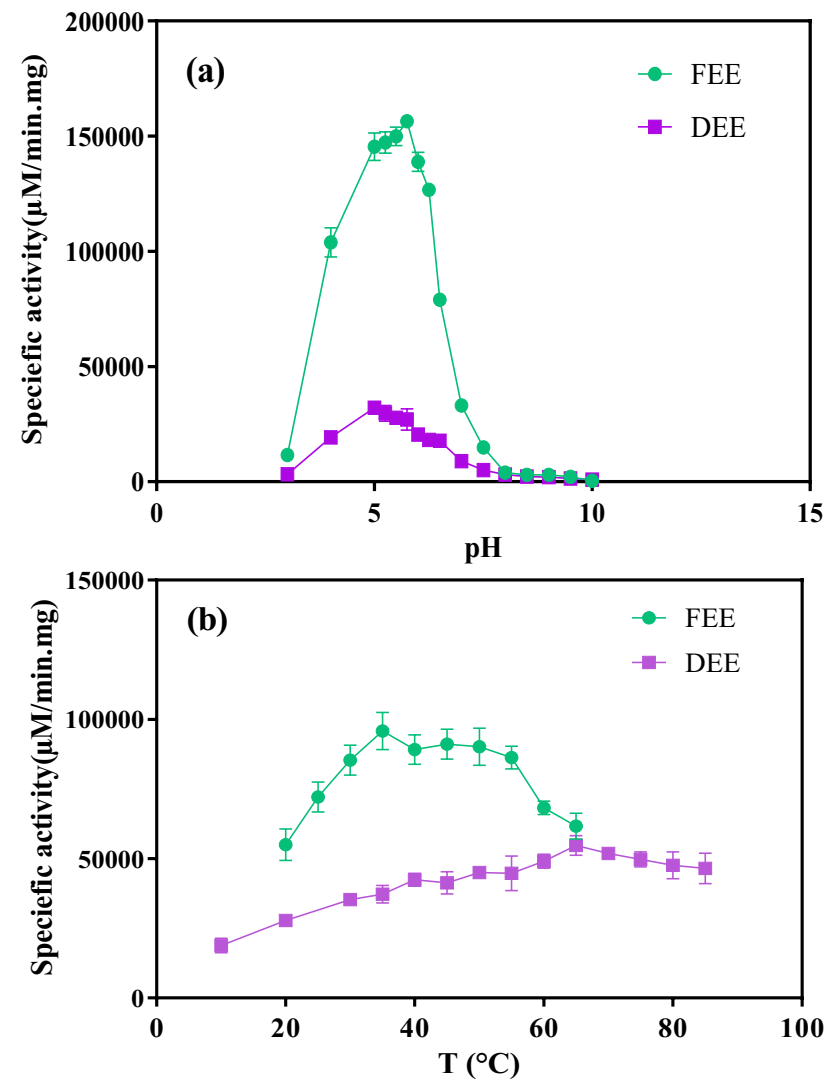

Figure 5. The optimum conditions of the enzymatic reaction in the presence of the freshly extracted enzyme (FEE) and the dried extracted enzyme (DEE) (a) experiment at the ambient temperature and different $\mathrm{pH}$ ranges $(3-10)(\mathbf{b})$ at the optimum $\mathrm{pH}$ and different temperature ranges $\left(10-85^{\circ} \mathrm{C}\right)$.

enzyme activity. As the result, it was inferred that the optimum values of 5.75 and 5 can be considered for FEE and DEE, respectively. The effect of temperature on the enzymatic reaction at the obtained optimum $\mathrm{pH}$ has been shown in Fig. 5b. The optimum temperature of the reaction catalyzed by FEE and DEE was observed at about $35^{\circ} \mathrm{C}$ and $65{ }^{\circ} \mathrm{C}$, respectively. As can be seen in this figure, although the reduction in activity owing to drying is noticeable, the optimum temperature of the enzymatic reaction has been increased in the presence of peroxidase as powder form.

As shown in Fig. 5, the activity of the enzyme has been affected upon drying. The optimum pH shifted to the acidic $\mathrm{pH}$ in DEE compared with the FEE. Interestingly, the optimum temperature of the reaction for DEE is increased by more than 1.8 -folds.

Effect of drying on the kinetics of the peroxidase reaction. To evaluate the influence of initial concentrations of TMB on the product concentration of FEE and DEE, the experiments were carried out in the presence of different concentrations of TMB $(0.06-0.6 \mathrm{mM})$ and the obtained results are presented in Fig. S1 (Supporting file). As evident, at initial times of reaction (about until $3 \mathrm{~min}$ ), the slope of each line is constant and independent of the substrate concentration. Therefore, for each line, an initial rate was obtained in accordance with the initial substrate concentration. The reaction rates were obtained by dividing the obtained slope by the amount of protein content. The obtained results from Fig. S1, the initial slopes, and the reaction rates are presented in Table 4 for the dried enzyme and the fresh extracted one.

According to Eq. (4), by drawing the inverse of the reaction rates versus the initial substrate concentrations, the M-M parameters ( $K_{\mathrm{m}}$ and $V_{\max }$ constants) were obtained (Fig. 6a) as presented in Table 5. After obtaining the constants, the rate of the reaction could be calculated from the M-M equation for different concentrations. The calculated rates from the M-M equation and the experimental data are presented in Fig. $6 \mathrm{~b}$. As can be seen, a clear decrease in enzyme activity was observed in DEE. The calculations showed that the FEE activity was reduced by $48.9 \%$, on average, after the drying process.

In addition to the physicochemical properties, the kinetic parameters of peroxidase were also affected upon enzyme drying, which may be due to peroxidase structural changes. Based on the results, because of drying, the affinity of the enzyme to substrate increased and the maximum reaction rate $\left(V_{\max , \text { DEE }}\right)$ decreased. Indeed, amino hydrophilic acids are in the exterior structure of the enzyme, creating hydrogen bonds between the enzyme and the water molecules ${ }^{39}$. As a result of drying, the aqueous medium around the enzyme is removed, causing hydrogen bonds to break down ${ }^{40}$, which leads to an increase in the salt concentration followed by a change in the electrostatic interaction between charged amino acids ${ }^{41}$. These changes may cause a variation in 


\begin{tabular}{|l|l|l|l|l|}
\hline $\mathrm{C}_{0, \mathrm{TMB}}(\mathrm{mM})$ & Slope $_{\mathrm{DEE}}(\mu \mathrm{M} / \mathbf{m i n})$ & Slope $_{\mathrm{FEE}}(\mu \mathrm{M} / \mathbf{m i n})$ & Reaction rate $\left(\mathrm{Vs}_{\mathrm{DEE}}\right)(\mu \mathrm{M} / \mathbf{m i n} \mathbf{m g})$ & Reaction rate $\left(\mathrm{Vs}_{\mathrm{FEE}}\right)(\mu \mathrm{M} / \mathbf{m i n} \mathbf{m g})$ \\
\hline 0.06 & $1.44 \pm 0.07$ & $0.30 \pm 0.00$ & $9234 \pm 419$ & $22,087 \pm 109$ \\
\hline 0.09 & $2.11 \pm 0.19$ & $0.42 \pm 0.02$ & $13,508 \pm 1197$ & $30,439 \pm 1135$ \\
\hline 0.12 & $2.62 \pm 0.21$ & $0.46 \pm 0.03$ & $16,754 \pm 1338$ & $33,626 \pm 2051$ \\
\hline 0.15 & $3.24 \pm 0.03$ & $0.55 \pm 0.051$ & $20,723 \pm 172$ & $40,000 \pm 3736$ \\
\hline 0.18 & $3.69 \pm 0.20$ & $0.68 \pm 0.01$ & $23,613 \pm 1290$ & $49,487 \pm 842$ \\
\hline 0.2 & $4.36 \pm 0.29$ & $0.69 \pm 0.02$ & $27,938 \pm 1837$ & $50,329 \pm 1684$ \\
\hline 0.4 & $5.94 \pm 0.19$ & $0.93 \pm 0.00$ & $38,018 \pm 1245$ & $68,095 \pm 256$ \\
\hline 0.6 & $6.78 \pm 0.23$ & $0.97 \pm 0.04$ & $43,418 \pm 1446$ & $70,842 \pm 2637$ \\
\hline
\end{tabular}

Table 4. The slopes and the reaction rates at different initial concentrations of the substrate.
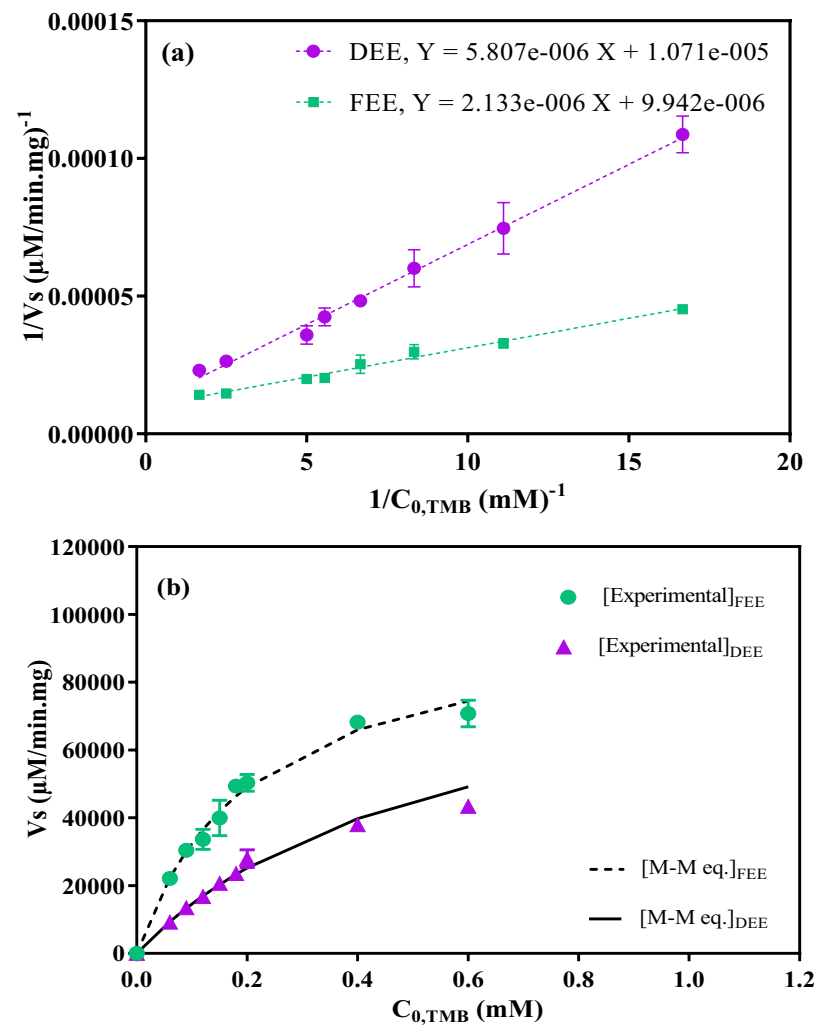

Figure 6. (a) Lineweaver-Burke Equation parameters "Eq. (4)" (b) The initial reaction rate obtained from the $\mathrm{M}-\mathrm{M}$ equation and the experimental data at different substrate concentrations using the dried extracted enzyme (DEE) and freshly extracted enzyme (FEE).

\begin{tabular}{|l|l|l|l|}
\hline $\mathbf{K}_{\mathrm{m}, \text { DEE }}(\mathbf{m M})$ & $\mathbf{K}_{\mathrm{m}, \mathrm{FEE}}(\mathbf{m M})$ & $\boldsymbol{V}_{\max , \text { DEE }}(\mu \mathrm{M} / \mathbf{m i n} \mathbf{~ m g})$ & $\boldsymbol{V}_{\max , \mathrm{FEE}}(\mu \mathrm{M} / \mathbf{m i n} \mathbf{m g})$ \\
\hline 0.54 & 0.21 & $93,370.68$ & $100,583.38$ \\
\hline
\end{tabular}

Table 5. The obtained kinetic parameters of the dried extracted enzyme (DEE) and freshly extracted enzyme (FEE).

the enzyme. Changes in kinetic properties as a result of enzyme structure variation during drying have been reported previously ${ }^{2-6}$.

Effect of drying on the thermal-stability and shelf-life during storage. Relative activity at each temperature indicates the ratio of the specific peroxidase activity at a specific temperature to the maximum specific peroxidase activity which is the specific peroxidase activity at $45^{\circ} \mathrm{C}^{42}$. As can be seen in Fig. 7 , the enzyme 


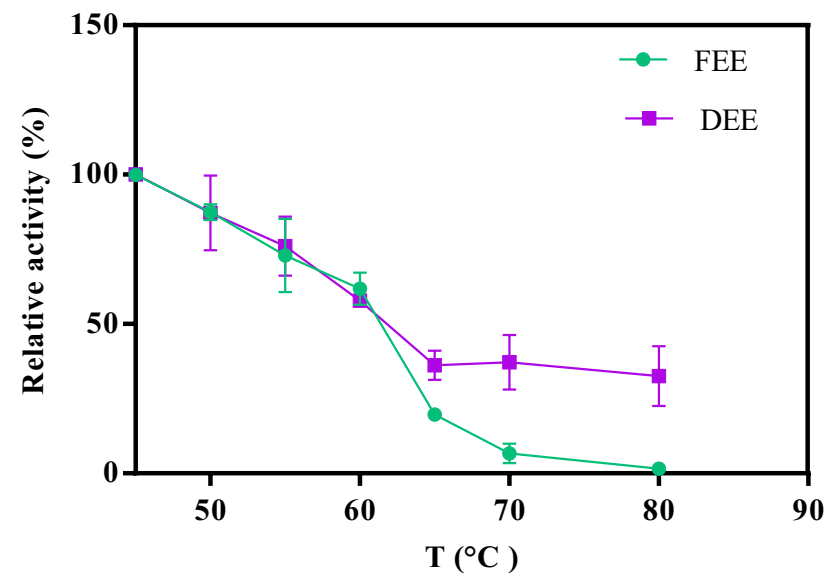

Figure 7. Thermal stability of the peroxidase as the dried extracted enzyme (DEE) and freshly extracted enzyme (FEE).

\begin{tabular}{|c|c|c|c|c|c|}
\hline Enzyme type & Dryer type & Operational factors & Residual enzyme activity (\%) & Stabilizer or adjuvant & Ref. \\
\hline Lipase & Spray dryer & $\begin{array}{l}\text { Inlet temperature of drying gas ( } 86.4 \text { to } 153.6 \\
\left.{ }^{\circ} \mathrm{C}\right) \text {, concentration of the drying adjuvant } \\
(1.95 \text { to } 12.05 \%) \text {, mass flow rate of the enzy- } \\
\text { matic extract }(2.63 \text { to } 9.36 \mathrm{~g} / \mathrm{min})\end{array}$ & $23-100$ & $\begin{array}{l}\text { Maltodextrin } \\
\beta \text {-cyclodextrin }\end{array}$ & Costa-Silva et al. ${ }^{44}$ \\
\hline a-amylase & Spray dryer & $\begin{array}{l}\text { inlet drying air temperature }\left(160-220^{\circ} \mathrm{C}\right) \text {, } \\
\text { feed ratio speed }\left(1.7-0.4 \mathrm{~cm}^{3} / \mathrm{s}\right)\end{array}$ & $51.9-91.8$ & Maltodextrin & Samborska et al. ${ }^{23}$ \\
\hline Lipase & Spray dryer & $\begin{array}{l}\text { Type of adjuvants (63-100\%)-without } \\
\text { adjuvants }\end{array}$ & $\begin{array}{l}6.73-100 \\
\text { Without adjuvants }=0\end{array}$ & $\begin{array}{l}\text { Lactose } \\
\beta \text {-cyclodextrin, maltodextrin, mannitol, gum } \\
\text { arabic, trehalose }\end{array}$ & Costa-Silva et al. ${ }^{24}$ \\
\hline Lipase & Spray dryer & $\begin{array}{l}\text { Type of adjuvants, Inlet temperature of } \\
\text { drying gas }\left(100,153.6^{\circ} \mathrm{C}\right) \text {, feed flow rate } \\
(4-9.36 \mathrm{~g} / \mathrm{min})\end{array}$ & $87.7-99.6$ & $\beta$-cyclodextrin, Lactose, Maltodextrin & Costa-Silva et al. ${ }^{45}$ \\
\hline Protease & Spray dryer & $\begin{array}{l}\text { Type of adjuvants, Inlet temperature of dry- } \\
\text { ing gas }\left(70-130^{\circ} \mathrm{C}\right)\end{array}$ & $79-94$ & Glucose, maltodextrin & Namaldi et al. ${ }^{22}$ \\
\hline Lipase & Spouted bed & Type of agricultural by-products & $83.6-179.1$ & $\begin{array}{l}\text { Rice husk, corn stover, sugarcane, bagasse } \\
\text { green, coconut fiber, corncob }\end{array}$ & Costa-Silva et al. ${ }^{17}$ \\
\hline
\end{tabular}

Table 6. Effect of stabilizer agents on the residual enzyme activity in different studies.

powder showed more stability toward heating compared to the extract one. For instance, at $80{ }^{\circ} \mathrm{C}$, enzyme extract activity tended to be zero, while more than $30 \%$ of the activity of enzyme powder was remained. Moreover, the shelf-life of the powder and extract was examined during storage. The peroxidase powder maintained $87.24 \%$ of its initial activity after storage at $-4{ }^{\circ} \mathrm{C}$ for 9 months while the peroxidase extract lost about $20 \%$ of its initial activity after one month of storage at the same temperature.

In accordance with Fig. 7, the thermal stability of the enzyme powder was improved during drying in the spouted bed. Although the increase of enzyme thermal-stability was reported by several methods ${ }^{2,41}$, to the best of our knowledge, this is the first time that the enhancement of peroxidase thermal-stability was reported by a drying process. The shelf-life of the DEE during storage was also improved owing to drying in the spouted bed, which is in agreement with the results of the enzyme drying in spray dryer ${ }^{43}$. Generally, improvement of optimum temperature, thermal stability, and shelf-life during storage has several advantages for the utilization of dried enzymes in industries which results in low-cost storage and long-time preservation as well as its use at higher temperatures ${ }^{1,9}$.

As shown in the results, the enzyme powder is active and more stable in the presence of heat, but the residual activity was relatively low. Therefore, further studies are needed to improve the residue activity as well as the other physicochemical properties of the dried enzyme by the use of protective or stable agents. Until now, several studies have been conducted and used some protective agents that are presented in Table 6.

\section{Conclusion}

The enzymes can be extracted directly from the natural resources of plants and animals; however, due to the short shelf-life of fresh enzymes, these materials should be dried. In this research, the root ingredients of garden radish which is a rich source of peroxidase were extracted and the resulting paste was dried using the spouted bed dryer with inert glass beads. The effect of important operating factors (the inlet air temperature and the air flow rate) and their interaction on the residual activity of enzyme were established by full factorial experimental design methodology for the first time. The ANOVA analysis indicated that the inlet air temperature, contrary 
to the air flow rate, had a negative effect on the residual activity of the enzyme. The obtained results indicated a reduction of the enzyme activity after the drying process which can be due to a change in peroxidase structure. After evaluating the optimum values of operating factors $\left(\mathrm{T}=50^{\circ} \mathrm{C}\right.$ and $\left.\mathrm{Q}=1.4\right)$, the effect of the drying process on the thermal-stability and kinetics of the peroxidase was investigated. The kinetic studies were carried out according to the Michaelis-Menton (M-M) equation, and $V_{\max }$ and $K_{\mathrm{m}}$ of enzymatic reaction were obtained for different TMB concentrations. According to the stability studies, it was confirmed that spouted bed drying of peroxidase had an impressive effect on the thermal-stability and shelf-life which improved up to $50 \%$ compare to the fresh enzyme. Overall, it could be concluded that the spouted bed dryer can be a promising method -as a successful unit operation for drying the heat-sensitive materials such as enzymes.

Received: 1 February 2021; Accepted: 28 June 2021

Published online: 13 July 2021

\section{References}

1. Mujumdar, A. S. (ed.) Handbook of Industrial Drying 981-990 (Taylor \& Francis, 2006).

2. Sarvandi-Dehghanpoor, E., Riahi-Madvar, A., Lotfi, S. \& Torkzadeh-Mahani, M. Improvement of kinetic properties and thermostability of recombinant Lepidium draba peroxidase (LDP) upon exposed to osmolytes. Int. J. Biol. Macromol. 119, 1036-1041 (2018).

3. Riahi-Madvar, A. \& Hosseinkhani, S. Design and characterization of novel trypsin-resistant firefly luciferases by site-directed mutagenesis. Protein Eng. Des. Sel. 22, 655-663 (2009).

4. Homaei, A. A., Sariri, R., Vianello, F. \& Stevanato, R. Enzyme immobilization: An update. J. Chem. Biol. 6, 185-205 (2013).

5. Zhou, X., Li, H. \& Zheng, L. Directly covalent immobilization of Candida antarctica lipase B on oxidized aspen powder by introducing poly-lysines: An economical approach to improve enzyme performance. Int. J. Biol. Macromol. 133, 226-234 (2019).

6. Zdarta, J., Meyer, A. S., Jesionowski, T. \& Pinelo, M. A general overview of support materials for enzyme immobilization: Characteristics, properties, practical utility. Catalysts 8, 92 (2018).

7. Farhadi, S., Riahi-Madvar, A., Sargazi, G. \& Mortazavi, M. Immobilization of Lepidium draba peroxidase on a novel Zn-MOF nanostructure. Int. J. Biol. Macromol. 173, 366-378 (2021).

8. Maltesen, M. J. \& Van De Weert, M. Drying methods for protein pharmaceuticals. Drug Discov. Today Technol. 5, e81-e88 (2008).

9. Araya-Farias, M. \& Ratti, C. Dehydration of foods: General concepts. In Advances in Food Dehydration (ed. Ratti, C.) 20-55 (Taylor \& Francis, 2009).

10. Hamid, M. Potential applications of peroxidases. Food Chem. 115, 1177-1186 (2009).

11. Azevedo, A. M. et al. Horseradish peroxidase: A valuable tool in biotechnology. Biotechnol. Annu. Rev. 9, 1387-2656 (2003).

12. Hatti-Kaul, R. Biotechnology (Eolss, 2009).

13. Kokkinakis, D. M. \& Brooks, J. L. Tomato peroxidase: Purification, characterization, and catalytic properties. Plant Physiol. 63, 93-99 (1979).

14. Motamed, S., Ghaemmaghami, F. \& Alemzadeh, I. Turnip (Brassica rapa) peroxidase: Purification and characterization. Ind. Eng. Chem. Res. 48, 10614-10618 (2009).

15. Riazi, Z., Ziai, S., Shariat, S., Farshchi, P. \& Khalili, F. Optimization of Garden radish (Raphanus sativus L.) Peroxidase Enzyme for Removal of 2, 4-dichlorophenol from 2, 4-Dichlorophenoxyacetic Acid Wastewater. Int. J. Environ. Res. 6, 519-530 (2012).

16. Zahidi, T. et al. Extraction and comparison of two new peroxidases from leaves and roots of Brassica oleraceae var. ramosa. J. Mater. Environ. Sci. 9, 1398-1404 (2018).

17. Costa-Silva, T., Cognette, R., Souza, C., Said, S. \& Oliveira, W. P. D. Spouted bed drying as a method for enzyme immobilization. Dry. Technol. 31, 1756-1763 (2013).

18. Hamedi, S., Afsahi, M., Nematollahi, M. \& Akhavan, H. Spouted bed drying of skimmed milk: multivariable optimization of the conditions to improve physicochemical properties of the dried milk. LWT 146, 111448 (2021).

19. Marreto, R., Freire, J. \& Freitas, L. Drying of pharmaceuticals: The applicability of spouted beds. Dry. Technol. 24, 327-338 (2006).

20. De Jesus, S. \& Maciel Filho, R. Drying of a-amylase by spray drying and freeze-drying-a comparative study. Braz. J. Chem. Eng. 31, 625-631 (2014).

21. Costa-Silva, T., Souza, C., Said, S. \& Oliveira, W. Drying of enzyme immobilized on eco-friendly supports. Afr. J. Biotechnol. 14, 3019-3026 (2015).

22. Namaldi, A., Çalik, P. \& Uludag, Y. Effects of spray drying temperature and additives on the stability of serine alkaline protease powders. Dry. Technol. 24, 1495-1500 (2006).

23. Samborska, K., Witrowa-Rajchert, D. \& Gonçalves, A. Spray-drying of $a$-amylase-The effect of process variables on the enzyme inactivation. Dry. Technol. 23, 941-953 (2005).

24. Costa-Silva, T. A., Nogueira, M. A., Fernandes Souza, C. R., Oliveira, W. P. \& Said, S. Lipase production by endophytic fungus Cercospora kikuchii: Stability of enzymatic activity after spray drying in the presence of carbohydrates. Dry. Technol. 29, 1112-1119 (2011).

25. Dotto, G. L., Souza, V. C. \& Pinto, L. A. Drying of chitosan in a spouted bed: The influences of temperature and equipment geometry in powder quality. LWT-Food Sci. Technol. 44, 1786-1792 (2011).

26. Kudra, T. \& Mujumdar, A. S. Special Drying Techniques and Novel Dryers (Marcel Dekker, 2006).

27. Fricks, A. T. et al. Evaluation of radish (Raphanus sativus L.) peroxidase activity after high-pressure treatment with carbon dioxide. J. Supercrit. Fluids 38, 347-353 (2006).

28. Bradford, M. M. A rapid and sensitive method for the quantitation of microgram quantities of protein utilizing the principle of protein-dye binding. Anal. Biochem. 72, 248-254 (1976).

29. Mujumdar, A. S. (ed.) Handbook of Industrial Drying 924-948 (Taylor \& Francis, 2006).

30. Mathur, K. B. \& Epstein, N. Spouted Beds (Academic Press, 1974).

31. Krainer, F. W. et al. Purification and basic biochemical characterization of 19 recombinant plant peroxidase isoenzymes produced in Pichia pastoris. Protein Expr. Purif. 95, 104-112 (2014).

32. Bezerra, R. P. et al. Extraction of amylase from fermentation broth in poly (ethylene glycol) salt aqueous two-phase system. Braz. Arch. Biol. Technol. 49, 547-555 (2006).

33. Montgomery, D. C. Design and Analysis of Experiments (Wiley, 2017).

34. Fattahian, Y., Riahi-Madvar, A., Mirzaee, R., Torkzadeh-Mahani, M. \& Asadikaram, G. Heterologous expression, purification and characterization of a peroxidase isolated from Lepidium draba. Protein. J. 36, 461-471 (2017).

35. Shuler, M. L. \& Kargi, F. Bioprocess Engineering Basic Concepts (Prentice Hall Inc, 2002).

36. Heidari, Z. et al. Degradation of furosemide using photocatalytic ozonation in the presence of ZnO/ICLT nanocomposite particles: Experimental, modeling, optimization and mechanism evaluation. J. Mol. Liq. 319, 114193 (2020). 
37. Pelalak, R. et al. Efficient oxidation/mineralization of pharmaceutical pollutants using a novel Iron (III) oxyhydroxide nanostructure prepared via plasma technology: Experimental, modeling and DFT studies. J. Hazard. Mater. 411, 125074 (2021).

38. Pelalak, R., Alizadeh, R., Ghareshabani, E. \& Heidari, Z. Degradation of sulfonamide antibiotics using ozone-based advanced oxidation process: Experimental, modeling, transformation mechanism and DFT study. Sci. Total Environ. 734, 139446 (2020).

39. Lodish, H. et al. Molecular Cell Biology (Macmillan, 2008).

40. Millqvist-Fureby, A., Malmsten, M. \& Bergenståhl, B. Spray-drying of trypsin-Surface characterisation and activity preservation. Int. J. Pharm. 188, 243-253 (1999).

41. Wang, W. Lyophilization and development of solid protein pharmaceuticals. Int. J. Pharm. 203, 1-60 (2000).

42. Chao, C. et al. Surface modification of halloysite nanotubes with dopamine for enzyme immobilization. ACS Appl. Mater. Interfaces 5, 10559-10564 (2013).

43. Ajmera, A. \& Scherließ, R. Stabilisation of proteins via mixtures of amino acids during spray drying. Int. J. Pharm. 463, 98-107 (2014).

44. Costa-Silva, T. A., Said, S., Fernandes Souza, C. R. \& Oliveira, W. P. Stabilization of endophytic fungus Cercospora kikuchii lipase by spray drying in the presence of maltodextrin and $\beta$-cyclodextrin. Dry. Technol. 28, 1245-1254 (2010).

45. Costa-Silva, T., Souza, C., Oliveira, W. \& Said, S. Characterization and spray drying of lipase produced by the endophytic fungus Cercospora kikuchii. Braz. J. Chem. Eng. 31, 849-858 (2014).

\section{Acknowledgements}

This research was supported by the Iranian National Science Foundation. The authors would like to thank the INSF for funding Project Number 96003659.

\section{Author contributions}

S.H.: Formal analysis, Writing_original draft, Validation. M.M.A.: Supervision, Editing, Methodology. A.R.-M.: Supervision, Editing, Validation. A.M.: Review and editing, Validation.

\section{Competing interests}

The authors declare no competing interests.

\section{Additional information}

Supplementary Information The online version contains supplementary material available at https://doi.org/ 10.1038/s41598-021-93563-4.

Correspondence and requests for materials should be addressed to M.M.A. or A.R.-M.

Reprints and permissions information is available at www.nature.com/reprints.

Publisher's note Springer Nature remains neutral with regard to jurisdictional claims in published maps and institutional affiliations.

(c) (i) Open Access This article is licensed under a Creative Commons Attribution 4.0 International License, which permits use, sharing, adaptation, distribution and reproduction in any medium or format, as long as you give appropriate credit to the original author(s) and the source, provide a link to the Creative Commons licence, and indicate if changes were made. The images or other third party material in this article are included in the article's Creative Commons licence, unless indicated otherwise in a credit line to the material. If material is not included in the article's Creative Commons licence and your intended use is not permitted by statutory regulation or exceeds the permitted use, you will need to obtain permission directly from the copyright holder. To view a copy of this licence, visit http://creativecommons.org/licenses/by/4.0/.

(c) The Author(s) 2021 